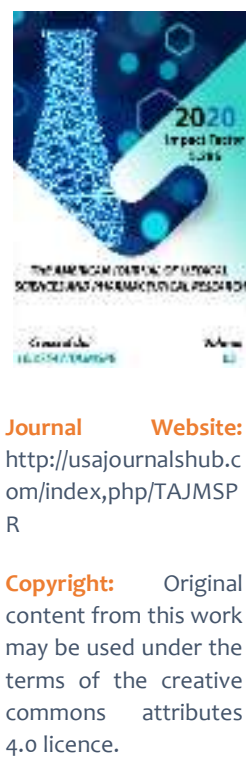

\title{
Optimization Of Local Treatment Of Patients With Phlegmon Of The Face And Neck Using Modern Antiseptics
}

\author{
Rustamova G.A \\ Samarkand State Medical Institute, Samarkand, Uzbekistan \\ Ten V.I. \\ Samarkand State Medical Institute, Samarkand, Uzbekistan
}

Rustamov A.A.

Tashkent State Dental Institute, Tashkent, Uzbekistan

\section{ABSTRACT}

Maxillo-facial area phlegmon is a common, serious, costly and deadly disease. Over the last decade, the attention of researches and clinical was focused on the search the optimal methods of diagnosis and treatment of this pathology. It is necessary for timely initiation of adequate causal antibiotic therapy and prevention of complications. Gas chro- matography - mass-spectrometry is one of the most powerful analytical methods to obtain data on the exciter. The review highlights the current understanding of the role and potential of the method in the improvement of measures aimed at prevention and treatment of phlegmons and their complications.

\section{KEYWORDS}

Maxillo-facial area phlegmons, gas chromatography - mass-spectrometry

\section{INTRODUCTION}

The article presents the results of a comparative study of the effectiveness of local treatment of postoperative wounds in patients diagnosed with phlegmon of the face and neck using a combined drug based on silver sulfatiazole
One of the most complex and urgent problems of modern purulent surgery is the treatment of patients with phlegmon of the face and neck. This pathology is characterized by a wide prevalence, difficulties in diagnosis at an early 
stage of the disease and a severe course, often leading to a fatal outcome.

Phlegmons of the face and neck occur as a result of endogenous infection, which causes a wide range of microbial pathogens of this purulent-inflammatory process and, often, low reactivity of the patient's body. Phlegmons of the face and neck are divided according to the source of infection:

in inflammatory processes of the tooth, odontogenicphlegmons are formed [1-3];

when the infection spreads from the foci of chronic inflammation of the upper respiratory tract, tonsillogenicphlegmons are formed;

often, the cause of neck phlegmon is esophageal perforation or suppuration of the median neck cyst $[2,4]$.

The most frequent pathogens of phlegmon of the face and neck are various strains of streptococci and staphylococci $[5,6]$ that persist on the mucous membranes, carious teeth, and chronic foci of oral inflammation. A significant role in the occurrence and development of the disease is also played by more aggressive microflora, which often gets into the wound a second time, due to reinfection. In this case, the pathogens often become nosocomial strains of microorganisms that have all the characteristics characteristic of this group: significant antibiotic resistance [7-9], high virulence, the ability to form bacterial biofilms on the wound surface, and resistance to most antiseptic agents used for local wound treatment $[10,11]$.

Patients diagnosed with phlegmon of the face or neck often have a decrease in the immune status [12-14], which leads to a prolonged course of the disease. In the presence of severe concomitant pathology, especially in the elderly and senile, immunodeficiency leads to frequent complications. The most common complications of facial and neck phlegmon are cavernous sinus thrombosis, anterior (usually) mediastinitis, multiple organ failure, and severe septic conditions [15]. As a result, in severe and prolonged course of the discussed pathology, the mortality rate is quite high, which, depending on the methods of surgical treatment used, the applied antibacterial drugs and local antiseptics, is from 10 to $25 \%$ [9].

The severe course of the disease, high lethality, and widespread polyresistance of pathogens to antibacterial drugs, which significantly reduces the effectiveness of antibiotic therapy, lead to the need to search for new drugs and complex drug compositions intended primarily for local treatment of this pathology [16-18]. The most promising scientific and practical direction is to develop tools with a strong antibacterial action, preventing the infection of wounds hospital strains, and cause more slow development of resistance in pathogens of purulent process, as well as supporting in the wound is essential for normal healing moisture.

In recent years, a fairly large number of antiseptics and medicinal compositions that meet these requirements in one way or another have been developed and proposed for introduction into clinical practice. For example, wound dressings that contain antibacterial components, ensure the outflow of wound exudate and maintain a moist environment on the surface of the postoperative wound have proven themselves well. But their use is limited to active suppuration in the wound.

One of the promising directions is the use of Argosulfan ${ }^{\circledR}$ in the complex local treatment of patients with phlegmon of the face and neck, which meets all the necessary requirements and is a combined preparation based on silver (silver sulfatiazole) and sulfonamide 
preparations. The range of applications of silver sulfatiazole is quite wide: pyoderma, bedsores, trophic ulcers of various origins (with chronic venous insufficiency, postthrombophlebitis, obliterating endarteritis, circulatory disorders against the background of diabetes), purulent and chronic long-term non-healing wounds, as well as minor domestic injuries (cuts, abrasions).

In recent years, this drug has been actively used in the treatment of a number of surgical diseases [19-22]. Thus, there is a prospect of using the drug for phlegmon of the face and neck for local treatment of wounds in the postoperative period. The antibacterial properties of various silver compounds (ions, salts, nanoparticles) against many pathogens of purulent-inflammatory diseases, including antibiotic-resistant nosocomial microflora, are widely known. Silver compounds can damage the cell wall of microorganisms, inactivate respiratory chain enzymes, and bind to the nucleic acids of the pathogen of the purulent process [23, 24]. The ability of silver to exert a pronounced inhibitory effect on bacterial and fungal cells (the effect of silver compounds on viral particles was also noted [25]) and its significantly lower toxicity to human cells [26, 27]. An important aspect is also the ability of silver to penetrate bacterial biofilms, which are usually resistant to antibacterial drugs and antiseptics [28-30].

The combined use of silver compounds and sulfonamide preparations can enhance the bactericidal properties of the resulting composition and compensate for the relatively weak resistance of silver compounds to physical and chemical environmental factors, such as chlorides present in the wound and light radiation. In addition, according to some literature sources [31, 32], silver sulfatiazole can enhance the regeneration processes in the wound, accelerate the proliferation of fibroblasts and keratinocytes, promoting the growth of granulations and epithelization of the wound defect.

Objective: to evaluate the effectiveness of Argosulfan ${ }^{\circledR}$ cream in the complex local treatment of patients with phlegmon of the face and neck.

\section{MATERIAL AND METHODS}

We treated 38 patients with a diagnosis of phlegmon of the face and neck aged 21 to 66 years with a mild to moderate course of the disease. Criteria for inclusion in the study: the prevalence of purulent-inflammatory process in 3 or more cellular spaces of the face and neck and the absence of complications at the time of treatment (mediastinitis, sepsis, multiple organ failure), voluntary informed consent to participate in the study. All patients received systemic treatment according to the Protocol.

The study participants were randomly divided into 2 equal groups, similar in gender, age, and the presence of comorbidities.

The comparison group (group 1) included 19 people who underwent standard local treatment of purulent-inflammatory process of cellular spaces, which included active surgical treatment of phlegmon, drainage of the postoperative wound using polyvinyl chloride single-light drains, as well as antibacterial therapy according to the results of seeding of wound exudate. In addition, desensitizing, infusion, and detoxification therapy was performed, according to the severity of the disease and concomitant pathology. Local treatment included cleaning the postoperative purulent wound with an aqueous $0.02 \%$ solution of chlorhexidinebigluconate and applying ointment dressings (Levomekol 
ointment) with a solution of iodopirone twice a day.

The main group (group 2) included 19 people who, in addition to the treatment regimen described above, were prescribed locally the drug Argosulfan ${ }^{\circledR}$. Before applying the dressing, the wound was additionally treated with this drug, after which standard treatment was performed.

Bandages in both groups were changed 2 times a day until signs of granulation tissue growth appeared, after which the wound was sutured with secondary sutures.

A complex of clinical, cytological, microbiological and laboratory research methods was performed to assess the effectiveness of the drug used.

Identification of the pathogen of the purulentinflammatory process and its sensitivity to antibiotics was carried out by aspiration of wound exudate using a sterile cotton swab. The resulting material was placed in a culture medium, the clinical isolate was identified, and the resistance to antibacterial drugs was evaluated by the disk method. The study of the material for the presence of anaerobic microflora was not performed. Material was collected for the study on the 1st, 4th and 7th days from the moment of hospitalization and surgical intervention.

The area of the wound defect was determined by Y. P. Savchenko [33], using computer image processing of the wound together with a standard of known area.

Clinical assessment of the course of the disease in the postoperative period included determining the timing of final wound cleansing, the timing of wound suturing, the period of pain relief, the timing of signs of granulation tissue growth and epithelization of the sutured wound, and body temperature. A General blood test was performed, and the leukocyte index of intoxication was determined.

To assess the dynamics of postoperative wound healing, we used the method of smearsprints from the wound surface, which allows us to obtain information about the priority cellular composition of the wound surface and the degree of readiness of the wound for suturing, as well as to identify early signs of possible repeated suppuration of the wound.

Nonparametric methods of statistical analysis were used to determine the reliability of the results obtained due to a small sample. Differences between the groups were considered significant at $p<0.05$.

\section{RESULTS AND DISCUSSION}

During the microbiological examination of the wound discharge, Staphylococcus bacteria (Staphylococcus aureus and Staphylococcus epidermidis) were most often sown) and streptococci (Streptococcus anginosus and Streptococcus pyogenes). The number of microorganisms in the wound progressively decreased from 105-106 CFU / ml of wound discharge on day 1 to 102-103 CFU / $\mathrm{ml}$ on day 7 of the study. At the same time, in the main group, by the 4th day of treatment, a decrease in the level of bacterial contamination was noted, and by the 7th day, almost complete elimination of the pathogen was observed. In the comparison group, there was only a slight decrease in the level of microbial bodies on the 4th day, and by the 7th day, bacterial bodies were still found in a small amount.

In the experimental group, the body temperature normalized on the 3 rd-4th day (3.57 \pm 0.43$)$, while in the comparison group, the temperature decreased on the 5th-6th 
$(5.64 \pm 0.28)$ day after surgical treatment $(p<0.05)$.

General blood analysis and leukocyte intoxication index did not reveal significant differences between the clinical groups, while differences in the clinical course of the wound process were significant. Pain relief in patients of the experimental group occurred earlier and took $2.34 \pm 0.12$ days versus more than 4 days in patients of the comparison group $(p<0.05)$.

When using Argosulfan ${ }^{\circledR}$ cream, there was also an earlier cleaning of the wound, the appearance of granulation tissue (on the 4th- 6th day), a change in the nature of the wound discharge and, accordingly, the application of secondary sutures (on the 10th day). There was no need for repeated surgical treatment of the wound in the postoperative period. There were no cases of repeated suppuration of the wound and/or divergence of sutures after suturing in any of the study groups. Assessment of the cellular composition of smears also confirms the acceleration of wound healing processes when using Argosulfan ${ }^{\circledR}$ silver-containing agent. On day 3 , a large number of neutrophils were observed when using ointment dressings (Fig. 1).

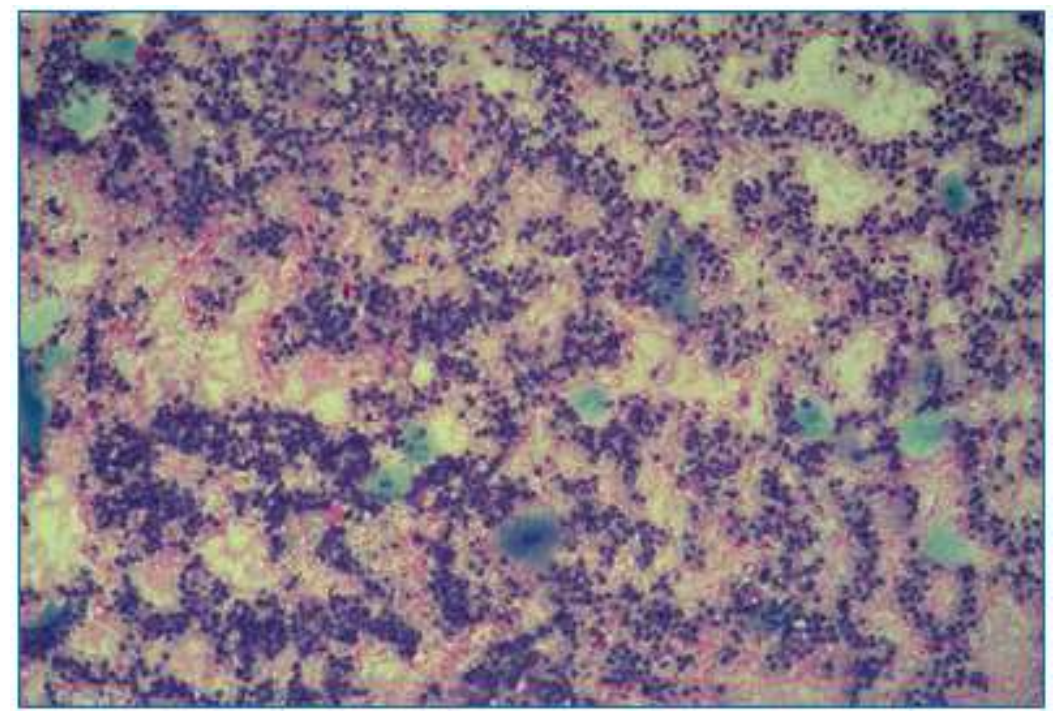

Fig.1 Expressed leukocyte reaction in a smear-print from the wound surface of a patient

\section{from the comparison group on the third day of the study}

On the 5th day of application of Levomekol ointment, the appearance of macrophages in smears-prints was noted, but at the same time a large number of neutrophilic leukocytes remained, fibroblasts were represented by single cells or were absent (Fig. 2). 


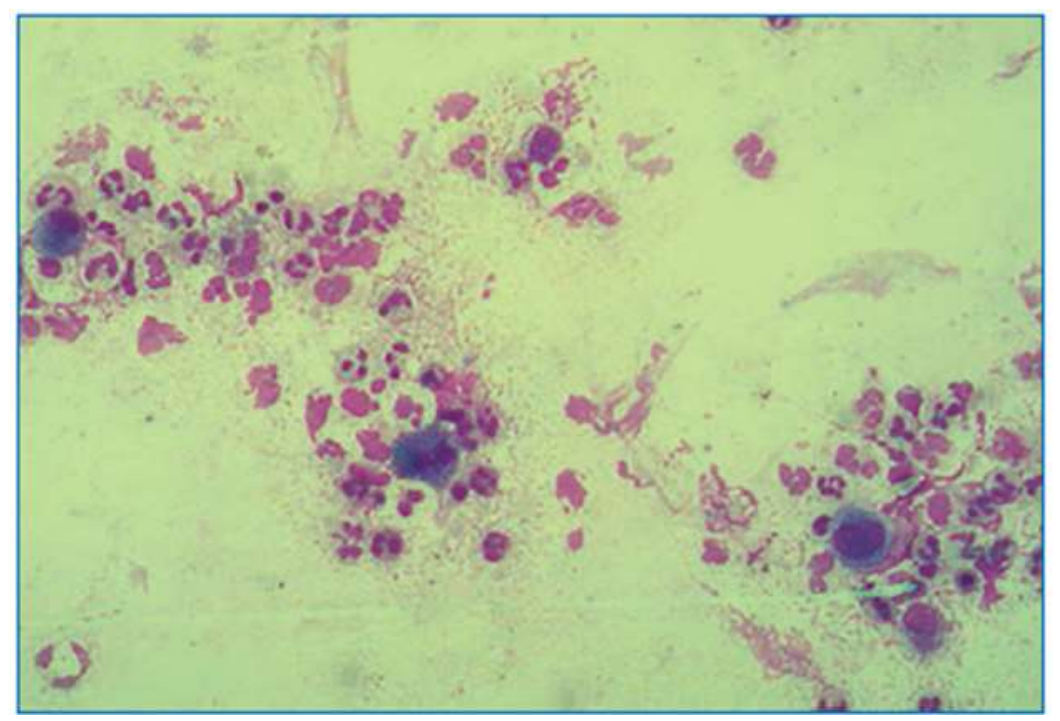

Fig.2 Macrophages on the background of white blood cells in a smear print from the wound surface of a patient from the comparison group on the 5th day of the study

When using a combined preparation of silver and sulfonamide compounds, fibroblasts were detected in the smears on the 4 th day (Fig. 3).

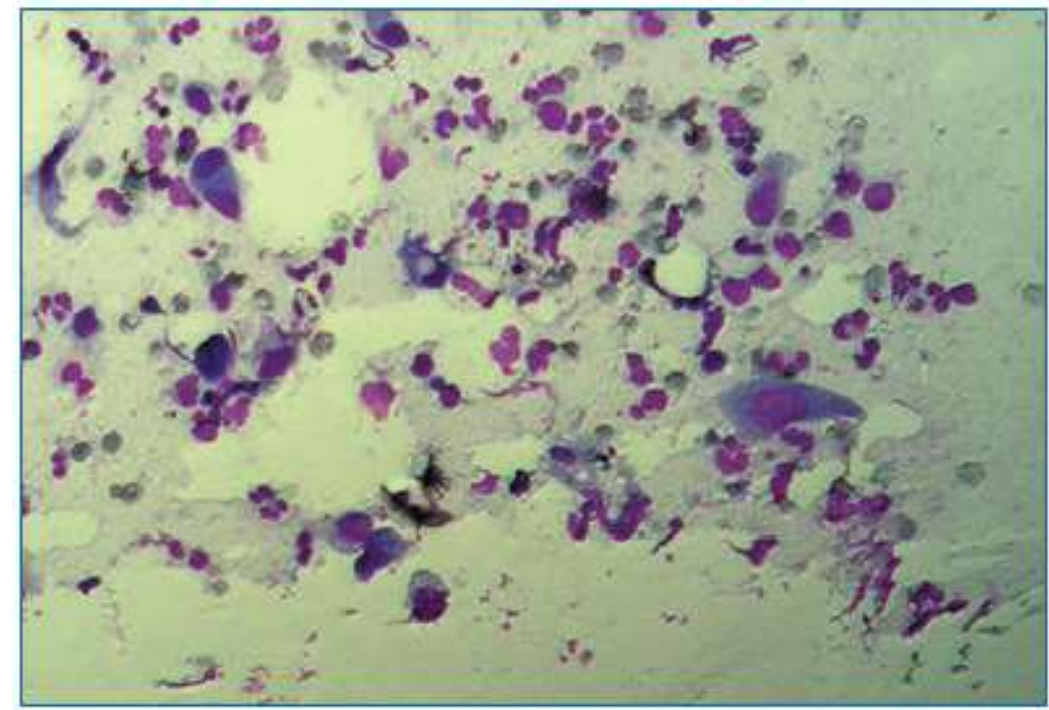

Fig. 3 Fibroblasts on the background of neutrophilic leukocytes in a smear-print from the wound surface of patients with phlegmon of the face and neck from the main group on the 4th day of the study 
When using ointment dressings, the pain syndrome lasted on average 2 days longer, and the appearance of granulation tissue was observed 2 days later, compared to the use of silver sulfatiazole. Wound suturing was performed when using Argosulfan ${ }^{\circledR}$ on average on the 10th day, when using ointment dressings - on the 12th day. The length of hospital stay when using Argosulfan ${ }^{\circledR}$ was also reduced by an average of 1.5 days (table 1 ).

Table 1.

\begin{tabular}{|c|c|c|}
\hline Parameter & Comparisongroup 1 & Comparisongroup2 \\
\hline Painsyndrome & $4,44 \pm 0,37$ & $2,34 \pm 0,18$ \\
\hline $\begin{array}{c}\text { Timing of appearance of } \\
\text { granulation tissue }\end{array}$ & $6,75 \pm 0,39$ & $4,41 \pm 0,73^{*}$ \\
\hline The timing of wound \\
closure & $12,27 \pm 0,32$ & $10,28 \pm 0,44^{*}$ \\
\hline Duration of hospital stay & $16,42 \pm 0,34$ & $14,85 \pm 0,38^{*}$ \\
\hline
\end{tabular}

When using the combined preparation Argosulfan ${ }^{\circledR}$, there was no drying of the dressing to the wound surface, which was generally typical for treatment with ointments and indicated drying of the wound surface. In General, the drying of bandages led to an increase in the time spent on performing bandages, and slowing down the regeneration processes in the wound. It should be noted that when using Argosulfan ${ }^{\circledR}$, the best cosmetic properties of postoperative scars were observed.

\section{CONCLUSION}

As a result of a clinical study, a relatively high effectiveness of topical application of Argosulfan ${ }^{\circledR}$ cream in the complex treatment of phlegmon of the face and neck was proved. The use of silver sulfatiazole made it possible to provide an antibacterial effect on the pathogens of the purulent-inflammatory process and maintain the humidity necessary for optimal wound healing. The use of this tool made it possible to reduce the time of cleaning and suturing the wound in the postoperative period. Also, the use of this drug made it possible to achieve the best cosmetic effect due to a less pronounced scar when healing a sutured wound.

\section{REFERENCES}

1. Ilyano V.M. The state of the prostaglandin system in patients with chronic periodontitis // Zagal'napatologiya and 
pathologicnaphiziologiya. 2012. Vol.7. No.
4.
P.191-196
[II'jano
V.M.

Sostojaniesistemyprostaglandinov u

bol'nyh s hronicheskimperiodontitom //

Zagal'napatologijatapatologichnafiziologij

a. 2012. V.7. No. 4.S.191-196 (in Russian)].

2. Marchiano E., Raikundalia M.D., Carniol E.T. et al. Characteristics of patients treated for orbital cellulitis: An analysis of inpatient data // Laryngoscope. 2016. Vol. 126 (3). R.9.

3. Yuldashev I.M., Urgunaliev B.K., Ashinaliev A.A. et al. Total odontogenic mediastinitis as a complication of putrefactive necrotizing phlegmon of the bottom of the oral cavity // Pacific Medical Journal. 2011. No. 3. Pp. 97-98 [Juldashev I.M., Urgunaliev B.K., Ashinaliev A.A. i dr.Total'nyjodontogennyjmediastinitkakos lozhneniegnilostnonekroticheskojflegmon ydnapolostirta

Tihookeanskijmedicinskijzhurnal. 2011. No. 3. S.97-98 (in Russian)].

4. Brea Álvarez B., Esteban García L., Tuñón Gómez M., Cepeda Ibarra Y. Nontraumatic head and neck injuries: a clinical approach. Part 2 // Radiologia. 2017. Vol. 59 (3). P.182195.

5. Huseynova M.G., Bisaev U.I. Pharmacotherapy of phlegmon and odontogenic osteomyelitis of the jaw bones // Bulletin of medical Internet conferences. 2017. Vol.7. No. 6. P.1279 [Gusejnova M.G., Bisaev U.I. Farmakoterapijaflegmony odontogennogoosteomielitacheljustnyhk ostej // Bjulleten 'medicinskih internetkonferencij. 2017. V.7. No. 6.S.1279 (in Russian)].

6. Hirasawa K, Tsukahara K, Motohashi R et al. Deep neck cellulitis: limitations of conservative treatment with antibiotics // ActaOtolaryngol. 2017. Vol. 137 (1). P.8689.
7. Monakov VA, Ivashchenko AV, Reshetnikova VP Features of the microbiological picture of wounds in patients with odontogenic phlegmons of the maxillofacial area using vacuum therapy // Clinical dentistry. 2014. No. 1(69). S. 40-43 [Monakov V.A., Ivashhenko A.V., Reshetnikova V.P. 2014. No. 1 (69) .S.40-43 (inRussian)].

8. Kulikovsky V.F., Oganesyan V.F. Mortality in non-clostridial anaerobic infection of the soft tissues of the maxillofacial region and neck // Bulletin of Experimental and Clinical Surgery. 2010.T.3. No. 4. Pp. 373-376 [Kulikovskij V.F., Oganesjan V.F. Letal'nost 'prineklostridial'nojanajerobnojinfekciimja gkihtkanejcheljustno-licevojoblasti i shei // Vestnikjeksperimental'noj klinicheskojhirurgii 2010. V.3. No. 4.S.373376 (in Russian)].

9. Lin Y.Q., An L.F., Li L. New treatment choice of head and neck cellulitis: multi-catheter drainage guided by ultrasound percutaneous puncture // ZhonghuaEr Bi Yan HouTou Jing WaiKeZaZhi. 2017. Vol. 52 (2). P.110-112.

10. Subkhanova G.S. Comparative analysis of the effectiveness of dressings in the treatment of purulent wounds of the face and neck // Bulletin of Avicenna. 2013. No. 2 (55). Pp. 117-123 [Subhanova G.S.Sravnitel'nyjanalizjeffektivnostiperevja zochnyhsredstv $v$ lecheniignojnyhranlica $\mathrm{i}$ shei // VestnikAvicenny. 2013. No. 2 (55). S.117-123 (inRussian)].

11. Ketova G.G., Latyushina L.S., Dolgushin I.I. Pharmacoeconomic analysis of local use of immunopreparations in the complex treatment of patients with odontogenic phlegmon // Problems of standardization in health care. 2009. No. 3-4. Pp. 30-35 [Ketova G.G., Latjushina L.S., Dolgushin I.I.Farmakojekonomicheskijanalizmestnog 
oprimenenijaimmunopreparatov $\mathrm{v}$ kompleksnomlecheniibol'nyh s odontogennymiflegmonami Problemystandartizaoocih vendravii. 2009. No. 3-4. S.30-35 (inRussian)].

12. Barannik N.G., Varzhapetyan S.D., Sidoryako A.V. and others. Changes in the immune status in phlegmon of the maxillofacial region depending on the prevalence of a purulent process // Zaporozhye medical journal. 2016. No. 1 (94). Pp. 44-49 [Barannik N.G., Varzhapetjan S.D., Sidorjako A.V. i dr. Izmenenieimmunnogostatusapriflegmona hcheljustno-licevojoblasti $\mathrm{v}$ zavisimostiotrasprostranjonnostignojnogo processa

Zaporozhskijmedicinskijzhurnal. 2016. No.1 (94). S.44-49 (in Russian)].

13. Taub D, Yampolsky A, Diecidue R, Gold L. Controversies in the Management of Oral and Maxillofacial Infections // Oral Maxillofac SurgClin North Am. 2017. Vol. 29 (4) P.465-473.

14. Kabanova S.A. The study of the immune status in purulent-inflammatory diseases of the maxillofacial region // News of surgery. 2005.T.13. No. 1-4. Pp. 28-32 [Kabanova S.A.

Izuchenieimmunnogostatusaprignojnovospalitel'nyhzabolevanijahcheljustnolicevojoblasti // Novostihirurgii. 2005. V.13. No. 1-4.S.28-32 (in Russian)].

15. Hirasawa K., Tsukahara K., Motohashi R. et al. Deep neck cellulitis: limitations of conservative treatment with antibiotics // ActaOtolaryngol. 2017. Vol. 137 (1). P.8689.

16. Monakov V.A. Hydrodynamic substantiation of aspiration and lavage drainage of purulent wounds // South Ural Medical Journal. 2015. No. 2. Pp.16-21 [Monakov V.A. Gidrodinamicheskoeobosnovanieaspiracion no-promyvnogodrenirovanijagnojnyhran // Juzhno-Ural'skijmedicinskijzhurnal. 2015. No. 2. S.16-21 (inRussian)].

17. Lishov E.V., Kharitonov A.A., Putintsev A.M. Features of surgical treatment of anaerobic infections of the deep spaces of the neck, complicated by mediastinitis // ActaBiomedicaScientifica. 2017.Vol.2. No. 6. S. 130-133 [Lishov E.V., Haritonov A.A., Putincev A.M. Osobennostihirurgicheskogolechenijaanaj erobnyhinfekcijglubokihprostranstvshei, oslozhnjonnyhmediastinitom // ActaBiomedica Scientifica. 2017. V.2. No. 6.S.130-133 (in Russian)].

18. Pérez-Díaz M. A., Silva-Bermudez P., Jiménez-López $B$. et al. Silver-pig skin nanocomposites and mesenchymal stem cells: suitable antibiofilm cellular dressings for wound healing. Nanobiotechnology. 2018. Vol. 16 (1). P.2.

19. Vinnik Yu.S., Serova E.V., Kukonkov V.A. and etc. Possibilities of using sulfathiazole in silver surgery // BC. 2017.T.25. No. 8. Pp. 529-532 [VinnikJu.S., Serova E.V., Kukonkov V.A. i dr. Vozmozhnostiprimenenijasul'fatiazolasere bra v hirurgii // RMZh. 2017. V.25. No. 8.S.529-532 (in Russian)].

20. Samtsov A.V., Telichko I.N., Statsenko A.V. The use of external agents containing silver compounds in the treatment of patients with pyoderma // Bulletin of Dermatology and Venereology. 2014. No. 1. Pp. 75-80 [Samcov A.V., Telichko I.N., Stacenko A.V. Primenenienaruzhnyhsredstv, soderzhashhihsoedinenijaserebra, v terapiibol'nyhpiodermijami // Vestnikdermatologii i venerologii. 2014. No. 1. S.75-80 (inRussian)].

21. Fedota N.V., Lukyanova D.A. Influence of ointments based on silver and zinc on skin regeneration when modeling thermal 
burns // Bulletin of the Orenburg State Agrarian University. 2014. No. 6 (50). Pp. 77-78 [Fedota N.V., Luk'janova D.A. Vlijaniemazejnaosnoveserebra i cinkanaregeneracijukozhiprimodelirovaniit ermicheskihozhogov IzvestijaOrenburgskogogosudarstvennog oagrarnogouniversiteta. 2014. No. 6 (50). S.77-78 (inRussian)].

22. Belousova T.A., Paramonov A.A., Goryachkina M.V. Local therapy of bacterial and necrotizing ulcerative lesions of the skin and soft tissues: the search for optimal solutions // Farmateka. 2014. No. 10 (283). Pp. 62-66 [Belousova T.A., Paramonov A.A., Gorjachkina M.V. Bestnajaterapijabakterial'nyh i nekroticheski-jazvennyhporazhenijkozhi i mjagkihtkanej: poiskoptimal'nyhreshenij // Farmateka. 2014. No. 10 (283). S.62-66 (inRussian)].

23. Bukina Yu.A., Sergeeva E.A. Antibacterial properties and mechanism of bactericidal action of silver nanoparticles and ions // Bulletin of Kazan Technological University. 2012.T.15. No. 14. Pp. 170-172 [BukinaJu.A., Sergeeva E.A. Antibakterial'nyesvojstva i mehanizmbaktericidnogodejstvijananocha stic i ionovserebra // VestnikKazanskogotehnologicheskogouni versiteta. 2012. V.15. No. 14.S.170-172 (in Russian)].

24. Kim M.H., Park H., Nam H.C. et al. Injectable methylcellulose hydrogel containing silver oxide nanoparticles for burn wound healing. CarbohydrPolym. 2018. Vol. (181). P.579-586.

25. Mosin O.V. Bactericidal properties of colloidal silver nanoparticles // Nanotechnology. Ecology. Production. 2013. No. 6 (25). Pp. 54-59 [Mosin O.V. Baktericidnyesvojstvananochastickolloidn ogoserebra // Nanotehnologii. Jekologija.
Proizvodstvo. 2013. No. 6 (25). S.54-59 (inRussian)].

26. Gmoshinsky I.V., Shiplin V.A., Vorozhko I.V. et al. Toxicological evaluation of nanosized colloidal silver stabilized with polyvinylpyrrolidone. III. Enzymological, biochemical markers, the state of the antioxidant defense system // Questions of nutrition. 2016.V.85. \# 2. Pp. 14-23 [Gmoshinskij I.V., Shipelin V.A., Vorozhko I.V.

dr.Toksikologicheskajaocenkananorazmer nogokolloidnogoserebra, stabilizirovannogopolivinilpirrolidonom.

III. Jenzimologicheskie, biohimicheskiemarkery, sostojaniesistemyantioksidantnojzashhity // Voprosypitanija. 2016. V.85. No. 2.S.14-23 (in Russian)].

27. Fastovets I.A., Verkhovtseva N.V., Pashkevich E.B. and etc. Silver nanoparticles: toxic effect on microorganisms and interaction with higher plants // Problems of Agrochemistry and Ecology. 2017. No. 1. S. 51-62 [Fastovec I.A., Verhovceva N.V., Pashkevich E.B. i dr.Nanochasticyserebra:

toksicheskoedejstvienamikroorganizmy i vzaimodejstvie s vysshimirastenijami // Problemyagrohimii i jekologii. 2017. No. 1. S.51-62 (in Russian)].

28. Ullah Khan S., Saleh T. A., Wahab A. et al. Nanosilver: new ageless and versatile biomedical therapeutic scaffold. Nanomedicine. 2018. Vol. 2 (13). P.733-762.

29. Tapalsky D.V., Osipov V.A., Sukhaya G.N. et al. Biocompatible composite antibacterial coatings to protect implants from microbial biofilms // Problems of health and ecology. 2013. No. 2 (36) .S. 129-134 [Tapal'skij D.V., Osipov V.A., Suhaja G.N. i dr.Biosovmestimyekompozicionnyeantiba kterial'nyepokrytijadljazashhityimplantato 
votmikrobnyhbioplenok

Problemyzdorov'ja i jekologii. 2013. No. 2 (36). S. 129-134 (in Russian)].

30. Percival S.L. Restoring balance: biofilms and wound dressings // J Wound Care. 2018. Vol. 27 (2). P.102-113. doi: 10.12968 / jowc.2018.27.2.102

31. Fedota N.V., Lukyanova D.A. Influence of ointments based on silver and zinc on skin regeneration when modeling thermal burns // Bulletin of the Orenburg State Agrarian University. 2014. No. 6 (50). Pp. 77-78 [Fedota N.V., Luk'janova D.A. Vlijaniemazejnaosnoveserebra cinkanaregeneracijukozhiprimodelirovaniit ermicheskihozhogov

IzvestijaOrenburgskogogosudarstvennog oagrarnogouniversiteta. 2014. No. 6 (50). S.77-78 (inRussian)].

32. Zinoviev E.V., Ivakhnyuk G.K., Lagvilava T.O. and other Substantiation of the feasibility of developing wound-healing formulations based on carbopol for the treatment of wounds in decompensated diabetes // Surgeon. 2013. No. 6. Pp. 47-53 [Zinov'ev E.V., Ivahnjuk G.K., Lagvilava T.O. dr. Obosnovaniecelesoobraznostirazrabotkira nozazhivljajushhihrecepturnaosnovekarbo polovdljalechenijaranpridekompensirovan nomdiabete // Hirurg. 2013. No. 6. S.47-53 (inRussian)].

33. Savchenko Yu.P., Fedosov S.R., Plaksin A.M. A method for determining the area of a skin defect and controlling its measurements. Patent for invention No. 2301626. Appl. November 17, 2005. Publ. June 27, 2007. B.18. $5 \mathrm{sec}$. [SavchenkoJu.P., Fedosov S.R., Plaksin A.M. Posobopredelenijaploshhadidefektakozhi i kontroljaejoizmerenij. Patentnaizobretenie No. 2301626. Zajavl. November 17, 2005. Opubl. June 27, 2007. B.18. 5 s. (inRussian)]. 